\title{
Lydia Amir
}

Tufts University, 419 Boston Ave, Medford, MA 02155, United States lydamir@mail.com

\section{Meaning, Happiness, and Misery - an Inquiry into Philosophy's Scope and Limitations}

\begin{abstract}
Publications in philosophical practice sometimes refer to the role philosophers had as doctors of the soul and subsequently maintain that practical philosophers should rekindle this role. One hundred fifty years after the birth of scientific psychology, this claim should be reassessed, and if found wanting, philosophy's possible role along the psychological doctors of the soul should be clarified. Thus, this article enquires into philosophy's contemporary usefulness for individuals by differentiating amongst the four or five main ways in which it can be practically helpful today.
\end{abstract}

\section{Keywords}

philosophy, usefulness, meaning, happiness, misery, ideals, tragic, absurd, Homo risibilis, impossible

The paper enquires into philosophy's contemporary usefulness for individuals. ${ }^{1}$ The double emphasis on contemporary uses of philosophy and its uses for individuals needs explaining. I briefly address the latter focus, which enlightens the relations between social and political questions, on the one hand, and existential issues, on the other, in order to expand on the former, the contemporary usefulness of philosophy.

Many social and political theorists have addressed existential questions late in their career. They note that these questions are implied in the political questions they dealt with. ${ }^{2}$ This is so because unless one shows that existential questions can be positively affected by social and political measures, the necessity of the latter is not clear. As the pessimistic controversy of the 19th century indicated, one of the motives for pessimistic attitudes toward the human condition was to prove that social measures will not make people happy. ${ }^{3}$ That existential questions are fundamental to philosophic reflection may be evident to philosophical practitioners, but it should be emphasised that they are at the root of all philosophic thought, if properly analysed.

The first focus of this paper's main question is on the contemporary usefulness of philosophy in contradistinction to the traditional uses it had. This is all the more important as for the last 150 years psychologists have taken up some of the traditional roles that philosophers used to fulfil. The term "doc-

Former versions of this paper were presented at APPA annual meeting and the online Russian conference of Philosophical Practice, both in July 2020.
One example is Jeff Noonan. See his argument on the relationship between existential questions and politics: Jeff Noonan, Embodiment and the Meaning of Life, McGill-Queen University Press, Montreal 2018, pp. xi-xii. 
tors of the soul" that was sometimes ascribed to philosophers takes us back to ancient philosophy.

"In ancient medicine, there were no psychiatrists, that is doctors (iatros) of the soul (psychē), but in ancient philosophy there were. From Democritus and Socrates onwards, numerous philosophers professed to be 'doctors of the soul', taking care of the ills of the soul analogously to the medical doctors taking care of the ills of the body. These ills were essentially emotional dispositions and responses conceived of as being detrimental to human happiness, and they were often referred to as 'diseases of the soul'. The philosophical therapy approaches varied, but they tended to be of the 'cognitive' kind. The idea of philosophy as therapy becomes especially prominent in Hellenistic philosophy (...). Philosophical therapies of this kind were intended for people troubled by worries, fears and dissatisfaction; they were not intended for people with medical disorders affecting the mind." ${ }^{4}$

From the ancient point of view, all medical disorders were disorders of the body, treatable by the same principles. Thus, ancient doctors were experts of bodily health and disease, while ancient philosophers were experts of psychic health and disease.

If philosophers were considered doctors of the soul, it was because they could teach how to eradicate passions, fears and desires, beliefs and theories by the use of virtue or wisdom conceived as acting in accordance to reality as seen by a certain school. For example, the Stoics attempted to infuse the idea of living according to nature to help us overcome our self-centred emotional hang-ups and to incite us it to find purpose in the cosmos by identifying with the cosmic reason (logos) governing all things; the Epicurean therapy sought to liberate us from unrealistic anxieties concerning death and the gods and to indicate how to be content through the basic satisfaction of our needs, and the Pyrrhonian sceptics urged us to discard superfluous beliefs in order to find peace of mind in the realisation that uncertainty is the only certitude.

As learning virtue was predicated on being rational, the mentally ill were usually excluded from such teaching. Marke Ahonen explored ancient philosophers' views of mental illness and showed that except for the Stoics, and especially Seneca ${ }^{5}$ who thought that philosophy could benefit the mentally ill although not cure them, the rest of the philosophers excluded the mentally ill from the philosophic discourse. ${ }^{6}$ The same can be said for early modern philosophy, as exemplified by Baruch Spinoza, who explicitly mentions the mentally ill (and children) as excluded from the benefits of his philosophy, which presupposes rational capacities.

What is unclear to us is the scope of the category of mentally ill, whether what we call personality disorders, as well as anxiety and depression, even in the guise of melancholy, were part of it. To take some examples, Aristotle considers melancholy positively, as the sign of the genius, and we do not have evidence in Hellenistic philosophies that the psychological conditions listed above were automatically excluded from philosophic discussions. Moreover, not only Aristotle analyses various forms of mental illness in his writings, Plato is notoriously vague about the forms of madness, apart from the discussion in the Laws. To make things worse, madness is used metaphorically by the Cynics, Stoics, Erasmus, Spinoza and Santayana, among others, to indicate the condition of the normal human being when oblivious of philosophy. However, in all these cases, it is clear that normal human insanity or folly is differentiated from mental illness.

Along with the problem of the scope of the patients that the philosophic doctors of the soul attended to, another significant point that impacts philosophi- 
cal medicine is the shift in the vision of mental health. Today, it is seen as unrelated to virtue or vice. I have explained elsewhere the reasons that account for this change and the impact it had on synoptic views of ethics. ${ }^{7}$ Since mental health has become an issue that is unrelated to ethical teaching, doctors of the soul are formed today in another discipline. Thus, the question of the usefulness of philosophy is all the more pressing. Unless philosophy wishes to compete with the new doctors of the soul, as some philosophical practitioners believe it should sometimes on the basis of a well-founded critique of psychiatry, psychoanalysis, psychology or psychotherapy, we should enquire into the contemporary role that philosophy can play in relation to individuals. The questions we should address, then, are: in which ways can philosophy benefit the individual, if at all? Are these ways unique, that is, is there something philosophers can do best than others? In what follows, I map the four or five main ways in which philosophy may serve the individual.

I begin by analysing the psychological notion of therapy to point out its essential difference from philosophic ideals. I further indicate how educating oneself in, and following any one of the various ideals that philosophy proposes is one way of making good use of philosophy. This way is characterised by the meaning it provides through handling the fear of meaningless suffering (Friedrich Nietzsche) ${ }^{8}$ Depending on the ideal chosen, this path sometimes minimises suffering along with the significance it grants it by pointing to the cause of suffering and the mechanism that can remove it.

Two criticisms of this path yield other uses of philosophy. One criticism states that meanings are lies, the other that ideals are ineffective, and each comes in either a gloomy or a cheerful version.

The first criticism leads to tragic philosophy. Differentiated from theories of the absurd, which are still predicated on meaning, tragic philosophies negate meaning and offer happiness instead. They can be further subdivided into gloomy (Clément Rosset) and cheerful theories of the tragic (Lydia Amir).

The second criticism of ideals as providers of meaning states that ideals are ineffective either because each person has to carve her wisdom or because wisdom cannot be attained. The cheerful version leads to a revision of philosophy, whose new role is to educate one's judgment (Michel de Montaigne). The gloomy version points to the limitations of philosophy, to the inefficacy of reason once personal tragedy is encountered with its concomitant isolating effect, where one feels disconnected from the rest of humanity as an unfor-

For the pessimist controversy, see: Frederick Charles Beiser, Weltschmerz: Pessimism in German Philosophy, 1860-1900, Oxford University Press, New York 2016.

4

Marke Ahonen, "Ancient Philosophers on Mental Illness", History of Psychiatry 30 (2019) 1, pp. 3-18, doi: https://doi. org/10.1177/0957154X18803508.

Cf. Caelius Aurelianus, Tardae passiones 1.166-167; quoted in: M. Ahonen, "Ancient Philosophers on Mental Illness", p. 14.
6

Cf. Marke Ahonen, Mental Disorders in Ancient Philosophy, Springer, Cham 2014.

7

Cf. the first chapter of Lydia Amir, Rethinking Philosophers Responsibility, Cambridge Scholars Publishing, Newcastle upon Tyne 2017.

Cf. Friedrich Nietzsche, The Gay Science, translated by Walter Kaufmann, Random House, New York 1974, "Preface", section 1; Friedrich Nietzsche, The Genealogy of Morals, translated by Walter Kaufmann, Reginald John Hollingdale, Vintage, New York 1967. 
tunate consequence of one's tragic fate (Lev Shestov). This view identifies solitude at the core of the philosophy of misfortune, which is inapproachable by regular philosophic tools. It remains to be seen if this approach still finds a role for philosophy or reverts either to literature or to religion for solace.

Hence the indecision above about the number of ways in which philosophy can be useful 150 years after the birth of scientific psychology. These ways eventually translate into various forms of philosophical practice, which can hopefully clarify the path taken by each philosophical practitioner.

The paper is divided into three parts that correspond to the three main ways in which philosophy can be useful for individuals today: the way of meaning given through the use of philosophic ideals, the criticism of meaning as lie provided by tragic philosophy, both in gloomy and cheerful versions, and the criticism of ideals as ineffective due to the lack of underlying uniformity, again, under a cheerful or a gloomy guise.

\section{Part I - Philosophic Ideals as Providers of Meaning}

The first path offers meaning through philosophic ideals. The history of philosophy has offered various ideals, which I believe are still valid today. The first was devised in the 5th century B.C and the last in the 20th century. They include, in historical order, the ideals of eudaimonia, ataraxia, personal philosophic redemption, self-realisation, and authenticity. We should also count, after the Greek and Hellenistic philosophic ideals, a non-philosophic ideal, the religious salus or salvation. However, salvation together with all philosophic ideals was superseded in the 20th century by a new psychological notion, "therapy".

My enquiry begins with an analysis of the psychological notion of therapy in order to point out its essential difference from philosophic ideals. This is important as it is rarely realised how the notion of therapy put forward by the new doctors of the soul, beginning with Sigmund Freud, revolutionises the previous philosophic (and religious) ideals. However diverse these ideals may be, together they differ from the new notion of therapy, as we will shortly see. But first, a brief account of Freud's vision of human possibilities should be given in order to understand his view of therapy.

We will never feel well for very long, according to Freud. As repression precludes Socratic self-knowledge, we will be deceived and humiliated time after time. We do not know who we are, what we desire and if we desire at all. The past is strong and subtle, unity is forged, and love deludes. We cannot love our fellowmen, who "have at best a mild contempt for us", and who, at worse, "nurture murderous rage". ${ }^{9}$ Nor can we change much; only partial liberation from hysterical misery to normal unhappiness is possible as "there will be no chance to redeem the inner State of Self with its divisions that Freud so ably describes". In other words, Mark Edmundson concludes:

"Freud is right about everything, once you have joined him in shrinking the world into certain dimensions." 10

Thus:

"Freud is distinct from the philosophers in that he offers no ideal (...) when you cordon off the great sources of human meaning that have arisen through the centuries and say that they are illusory (...). Freud can show you, through psychoanalysis and through the ethical program of his thought, how to feel a little better than you do (...). One will be told that there have been 
many developments in psychotherapy since Freud, and this may be true. But it will not be easy to find any therapeutic form advocating creative Eros, or the quest for unconditioned Truth, or risking one's life in a just cause, or selling what one has and living for the poor. Anyone who does such things, or even contemplate them, has left the regions of psychology behind. Any socalled therapy that enjoins ideals is no longer therapy. Therapy can have many values, but they will never be idealistic. All therapies are about learning to live with half a loaf." 11

Philosophy is utterly different from all psychological therapies in that it offers ideals.

One way of making good use of philosophy is educating oneself in these ideals intending to endorse one of them. As noted above, these ideals include eudaimonia or flourishing, in its Socratic, Platonic or Aristotelian guise; ataraxia or peace of mind, in its Stoic, Epicurean or Pyrrhonian versions; personal philosophic redemption - a revision of personal salvation, the ideal of the Middle Ages, now mixed with Enlightenment ideal of social progress, "redemption here and now" - in its Spinozistic, Schopenhauerian or Santayanan forms; the Romantic ideal of self-realisation, which can be exemplified by Nietzsche's philosophy, and finally, authenticity, the ideal of Existential philosophies, in their religious or atheist guise.

These ideals work by minimising the gap between ideal and reality, once an ideal is chosen, often according to one's temperament if arguments are brought to equipollence. They all have in common the following, however: they bring meaning to human life, and if they cannot minimise suffering, at least they console.

Some of these ideals minimise suffering by identifying its cause and the mechanism that may remove it. Both functions, minimising suffering and bestowing meaning, are predicated on a wider perspective, which should be known as true. This is why arguments are so important in philosophy. Ideals are couched in ethical terms, which are usually based on metaphysics. They work by explaining where we are (the nature of the world), what we are (human nature), what is wrong (diagnosing the human condition), and what we should do (prescribing a course of action). It is often forgotten that they can work only if one accepts the above, which means in philosophy that one knows or strongly believes that he knows the above. Thus, these ideals are predicated on philosophy as providing a wider context (which psychology cannot give unless it uncritically borrows from Eastern or Western philosophies). They provide us with sense also in the connotation of direction and bestow dignity on our struggle to improve.

The path of ideals is one way of making good use of philosophy. Nietzsche characterised the meaning it provides as handling the fear of meaningless suffering. Depending on the ideal chosen, this path sometimes also minimises suffering along with the significance it grants it. Two criticisms of this path yield other uses of philosophy. One critique maintains that meanings are lies and the other that ideals are ineffective, and each comes in a gloomy or in a cheerful version.

Mark Edmundson, Self and Soul: A Defense of Ideals, Harvard University Press, Cambridge (MA) 2015, p. 237.

10

Ibid., p. 244.
11

Ibid., pp. 242, 244-245. 


\section{Part II - Meanings are Lies}

The path of meaning has been variously attacked. One critical view argues that the problem is not to find the right meaning, but that meanings are lies. They answer our need to flee from the fear of suffering that meaningless suffering creates. As far as we know, however, the reality is not ordered in a cosmos that would be amenable to human understanding and would provide answers to our needs for knowledge, order, and meaning. To the contrary, hazard rules everything, "nature" does not exist, and our needs in this universe are not met or even acknowledged. Reality is tragic, and philosophy's role is to inoculate us, to prepare us for the shock the encounter with reality brings. We are doomed to know what we cannot withstand yet life requires us to eschew knowledge.

This criticism recommends a tragic philosophy. ${ }^{12}$ Tragic philosophies should be carefully differentiated from theories of the absurd, which are still predicated on meaning. The absurd is the idea of nature without the notion of finality. ${ }^{13}$ Anxiety, related as it is to the loss of an object, originates from the dispossession of what was assumed as given. Sense suddenly is missing, and the world is seen as absurd. To the contrary, the thought that we never possessed anything led many people to forgo anxiety. The disappearance of sense that tragic philosophies effectuate enables judging adequately that which happens to us. Correct judgment is predicated on witnessing the shipwreck of the model of intelligibility that underlies all human representations of intention and finality. Thus:

"If it is true that philosophy is first of all medicine, one way amongst others to cure oneself of anxiety, it is also true that this cathartic task can be conceived according to two forms of intention: one that reassures by restoring sense or another that reassures by utterly depriving us of sense. In both cases, the anguish that is activated by the fear of loss is discarded: nothing is lost or nothing can be lost, which also means the improbability of loss."14

The second way is tragic philosophy's way with its "logic of the worse". Contrary to appearances, however, tragic philosophy

"... does not provide greater security than the alternative way, the way taken by the majority of classical metaphysics. However, the temptation to possess, which continuously threatens tragic philosophy, is as powerful as the temptation to minimise the loss by integrating it within a more general perspective that continuously underlies the idealist and rationalist efforts. It is precisely the renouncement of all possessions that is suggested by the representation of a denaturised world." 15

Tragic philosophies negate meaning, yet they offer happiness. ${ }^{16}$ Becoming regains its innocence through the notion of hazard, as what happens is insignificant. While the insertion into a system of significations makes life guilty, the liberating simplicity of the real is accessed through tragic thought, and with this regained innocence comes happiness. Happiness is the only thing worth having: far from being predicated on anything else, it is independent of the nature of reality.

Tragic philosophies can be further subdivided into gloomy (Rosset) and cheerful theories of the tragic (Amir). According to the contemporary French philosopher, Rosset, happiness is predicated on the joy of life, a graced state that cannot be reached unless it is given in a mysterious way, which is entirely dissociated from that which happens. Nothing is changed yet we are joyful and happy, or not. ${ }^{17}$ According to Amir, Rosset's philosophy does not grant joy, as he acknowledges, yet a systematic path to stable joy can be accessed 
and followed by the Homo risibilis thesis Amir offers, through embracing the ridiculous human being that we all are. ${ }^{18}$

\section{Part III - Ideals are Ineffective}

The second criticism of the main path, the path of ideals, states that ideals are ineffective not because they are necessarily untrue; rather, the fault lies in the assumption of common human nature to which these ideals would correspond. According to this critical view, there is no common pattern to follow and no ideal to emulate. Again, this criticism comes in a cheerful and gloomy version: the cheerful one states that if we want to enjoy our lives rightfully, we each have to carve our own wisdom, and the gloomy one states that if we need to survive tragedy, there is no common path, which excludes the way of reason.

The cheerful version leads to a revision of philosophy, whose role now is to educate one's judgment. Presented coherently in Michel de Montaigne's Essais, it points the way to one's responsibility in carving one's wisdom, and the self-contentment that it brings. ${ }^{19}$ Montaigne cannot take the ideals of philosophy seriously. He is convinced that philosophers were not earnest in devising these principles: were they not men? Their human limitations contradict the very idea of philosophy as a system of ideals. He, at least, cannot follow any of them, nor does he believe that he should. Depicting himself as an accidental philosopher, who stumbles perchance on some lofty thought that another created, he writes the best document of practical philosophy ever written: The Essais (attempts) are an example, which cannot be emulated, of philosophy in practice. Essaying one's judgement on everyday problems and opinions is all we can do to live and die better, which is the goal of philosophy.

Montaigne's proposal is cheerful because he succeeds in saying yes to life and to himself, he triumphs through his humility where most boisterous philosophers failed. His vision ends in a theodicy or a cosmodicy that could and

12

For tragic philosophies, cf. the first chapter of Lydia Amir, Philosophy, Humor, and the Human Condition: Taking Ridicule Seriously, Palgrave Macmillan, London 2019.

13

This diagnosis of philosophies of the absurd is offered by Clément Rosset. Visions of the absurd are thoroughly analysed by Raymond Angelo Belliotti, Is Human Life Absurd? A Philosophical Inquiry into Finitude, Value, and Meaning, Brill - Rodopi, Leiden - Boston 2019.

14

Clément Rosset, L'Anti-nature: élements pour une philosophie tragique, PUF, Paris 1973, p. 72.

15

Ibid.

16

For happiness, cf. L. Amir, Rethinking Philosophers Responsibility, chapter 14.
17

Cf. Clément Rosset, e.g., La Philosophie tragique, PUF "Quadrige”, Paris 1991; Clément Rosset, Logique du pire, PUF “Quadrige", Paris 1993; Clément Rosset, L'Anti-nature: élements pour une philosophie tragique; and, in English, Clément Rosset, Joyful Cruelty: Toward a Philosophy of the Real, translated by David F. Bell, Oxford University Press, New York 1993.

18

Cf. L. Amir, Philosophy, Humor, and the Human Condition.

19

Cf. Michel de Montaigne, Les Essais de Michel de Montaigne, Pierre Villey, Verdun-Léon Saulnier (eds.), PUF, Paris 1965; Michel de Montaigne, The Complete Essays, translated by Donald Frame, Stanford University Press, Stanford 1958. 
should make other attempts pale. But his proposal is cheerful also because it is predicated on cheerfulness: folly is embraced as part of wisdom, and one's stupidity and ignorance, once all fights against them fail, are graced as part of human limitations..$^{20}$

The gloomy version points to the limitations of philosophy, to the inefficacy of reason once personal tragedy is encountered and one is disconnected from the rest of humanity as an unfortunate consequence. It is eloquently expressed in Lev Shestov's philosophy, which describes what happens when actual tragedy occurs in Everyman's life. The person who has encountered evil, or suffering considered unjustified and unjustifiable, experiences a crisis that may lead him to philosophy but to which philosophy cannot adequately respond. This is so because suffering excludes human company and isolates in a way that cannot be generalised. Caring becomes rarified in the new experience as all resources are summoned to help one's survival. Misery individualises and cannot be shared appropriately. Thus a philosophy of misery or misfortune can hardly be enacted on personal tragedy. ${ }^{21}$ Recall Arthur Schopenhauer's joke about the following conversation: "'I love to walk alone.' - 'Oh, so do I.' - 'So, let's walk together.'” Whilst there is no much to say about happiness, misery is diverse, as Leo Tolstoy already noted in Anna Karenina:

"Happy families are all alike; each unhappy family is unhappy in its own way." 22

Shestov's view identifies solitude at the core of the philosophy of misfortune, which is inapproachable by regular philosophic tools. It remains to be seen if this approach still finds a role for philosophy or reverts either to literature or to religion for solace. Hence the indecision at the beginning of this article about the number of ways (four, five) in which philosophy can be helpful 150 years after the birth of scientific psychology.

\section{Conclusion}

This article probed philosophy's usefulness in an age in which doctors of the soul are educated in another discipline. It proposed three main ways in which philosophy can be of help, which bifurcate into two additional paths. One way is to educate for ideals, in contradistinction to the modest and localised therapies proposed by various health practitioners. The main benefit of philosophic ideals is to produce meaning. Criticism of this path yields two alternative ways. One of them argues that, given the nature of reality, meaning is a lie; accordingly, the function of ideals as providers of meaning is to mislead us. The second alternative maintains that ideals are ineffective as the variety of human natures precludes the emulation of ideals.

The first alternative to meaning points to tragic philosophy that inoculates against the shock of reality and proposes happiness instead of meaning. Tragic philosophy should be differentiated from philosophies of the absurd that still yearn for meaning. The second alternative to ideals points to the need to educate our judgement so that we may be wise in our own way, learning to be content with ourselves by ourselves. This alternative brings meaning as well as happiness. ${ }^{23}$ The first way was diagnosed by Nietzsche, the second, by his follower Rosset, and the third by their precursor, Montaigne. ${ }^{24}$ Amir offers a cheerful and more viable alternative to Rosset whilst a goomier and pessimist alternative to Montaigne is offered by Shestov, who exchanges wisdom and 
happiness for lucidity about the enmity of reason and philosophy to personal tragedy.

The necessity of existential questions comes to the fore not only in personalist philosophies but also when social programs aim at providing happiness or meaning. This is why pessimism was fashionable in 19th century Germany and why political philosophers cannot escape addressing these questions even if late in life. The analysis of philosophy's scope and limitations that this article proposes and the various ways of philosophising that it identifies can help philosophical practitioners clarify the aim of their approach and evaluate its usefulness for the laymen they target.

\title{
Lydia Amir
}

\section{Smisao, sreća i jad - ispitivanje raspona i granica filozofije}

\begin{abstract}
Sažetak
Publikacije u filozofijskoj praksi ponekad se referiraju na ulogu koju su filozofi imali kao liječnici duše i nastavno na to smatraju da bi praktički filozofi morali njegovati tu ulogu. Sto i pedeset godina nakon rođenja znanstvene psihologije, ta bi se tvrdnja trebala ponovno razmotriti i nađe li se manjkavom, moguća uloga filozofije među psihologijskim doktorima duše trebala bi se razjasniti. Stoga ovaj rad razmatra aktualnu korisnost filozofije za pojedince, diferencirajući četiri-pet glavnih puteva njene upotrebljivosti danas.
\end{abstract}

\section{Ključne riječi}

filozofija, korisnost, smisao, sreća, jad, ideali, tragično, apsurdno, homo risibilis, nemoguće

20

On this point, cf. the first chapter of Lydia Amir, Laughter and the Good Life: Montaigne, Nietzsche, Santayana, SUNY Press, Albany, forthcoming.

21

Cf. Lev Shestov, Dostoevsky, Tolstoy and Nietzsche, translated by Spencer Roberts, Ohio University Press, Athens 1969; Lev Shestov, All Things are Possible (1905) and Penultimate Words and Other Essays (1908), Ohio University Press, Athens 1977. "The philosophy of misfortune" is the title of Alexis Philonenko's book, La Philosophie du malheur, tome 1: Chestov et les problèmes de la philosophie existentielle, Vrin, Paris 1998. In French, the connotation is much more powerful, as malheur is not only misfortune but misery or catastrophe.

22

"Toutes les familles heureuses se ressemblent, mais chaque famille malheureuse l'est à sa façon."
23

To have shown that reasonableness gives meaning is, following Baruch Spinoza, Richard Keshen's achievement. Cf. Richard Keshen, Reasonable Self-Esteem: A Life of Meaning, McGill-Queen University Press, Montreal 2017.

24

For further elaboration on Nietzsche, see Lydia Amir, Philosophy as Redemption: Spinoza and Nietzsche as Alternative Redeemers, de Gruyter, Berlin (forthcoming); on Rosset, see Chapter 3 of Lydia Amir, The Legacy of Nietzsche's Philosophy of Laughter: Bataille, Deleuze, Rosset, Routledge, New York 2020; and on Montaigne, see the first chapter of L. Amir, Laughter and the Good Life: Montaigne, Nietzsche, Santayana. 


\title{
Lydia Amir \\ Sinn, Glück und Elend - Ermittlung der Spannweite und Grenzen der Philosophie
}

\section{Zusammenfassung}

Die Publikationen in der philosophischen Praxis rekurrieren zuweilen auf die Rolle, die Philosophen als Ärzte der Seele spielten, und vertreten des Weiteren die Ansicht, dass praktische Philosophen diese Rolle fördern sollten. Einhundertfünfzig Jahre nach der Geburt der wissenschaftlichen Psychologie sollte diese Behauptung überdacht und, falls sie als mangelhaft befunden wird, die etwaige Rolle der Philosophie unter den psychologischen Ärzten der Seele geklärt werden. Daher wird in diesem Artikel die aktuelle Nützlichkeit der Philosophie für den Einzelnen ergründet, wobei zwischen vier bis fünf Hauptwegen ihrer Verwendbarkeit heutzutage differenziert wird.

\section{Schlüsselwörter}

Philosophie, Nützlichkeit, Sinn, Glück, Elend, Ideale, das Tragische, das Absurde, Homo risibilis, das Unmögliche

\section{Lydia Amir}

\section{Le sens, le bonheur et le malheur - étude du champ philosophique et de ses limites}

\begin{abstract}
Résumé
Les publications en philosophie pratique se réfèrent quelquefois au rôle que les philosophes avaient en tant que médecins de l'âme, et ainsi estiment que les philosophes pratiques devraient cultiver ce rôle. Cette proposition devrait être reconsidérée cent cinquante ans après la naissance de la psychologie scientifique. Si elle s'avère erronée, le rôle possible de la philosophie parmi les doctrines psychologiques devrait être précisé. Ainsi, ce travail analyse l'utilité actuelle de la philosophie pour les individus en faisant la différence entre quatre, cinq possibilités principales concernant son application aujourd'hui.
\end{abstract}

\section{Mots-clés}

philosophie, utilité, sens, bonheur, malheur, idéal, tragique, absurde, homo risibilis, impossible 